\title{
С.В.Сторожук,
}

доктор філософських наук, дочент НУБіП Украӥни,

I.C.Матвієнко, кандидат філософських наук, асистент НУБіП України

\section{ВИЩА ГУМАНІТАРНА ОСВІТА ТА МОЖЛИВОСТІ ФОРМУВАННЯ МОРАЛЬНОЇ ОСОБИСТОСТІ В УМОВАХ СУЧАСНОГО СУСПІЛЬСТВА}

Стан гуманітарної освіти в Україні зумовлює тривалі дискусії, які точаться навколо нагальних проблем, посталих в українському суспільстві. Яке місце займає гуманітарна освіта в нашій державі? Адже на Заході це -найбільший пласт програм, які викладаються у вищих навчальних закладах. Про яку високоосвічену особистість та гідного члена суспільства може йтися, коли скорочуються курси, спрямовані на розвиток та формування особистості? Чи можемо ми говорити про гарного урядовця, керівника, кваліфікованого спеціаліста, чи навіть політика, коли їхні знання обмежені лише окремою галуззю. Саме розширюючи світогляд кожного члена суспільства, ми формуємо культурну високоосвічену, духовно сильну та патріотичну націю. 3 огляду на це дослідження, присвячені гуманізації вищої освіти, сьогодні є надзвичайно актуальними.

Розгляд проблем філософії освіти ми можемо знайти ще в творах Арістотеля, який пропонував виховувати кожного члена суспільства заради розвитку всієї держави. За Нового часу наука посідає провідне місце, але ії значення мізерні без високорозвинутої особистості. Далі згадаємо І.Канта та його працю «Про педагогіку» та гегелівську «Енциклопедію філософських наук». Не можна не згадати про А.Шюца та багатьох інших. Сьогодні ця тема змінила свої координати в бік гуманізації освітнього процесу, що, на наш погляд, $\epsilon$ надзвичайно актуальним. Серед українських дослідників гуманізації вищої освіти не можна оминути увагою, насамперед, таких представників, як Р.А.Бєланова, С.У. Гончаренко, П.П.Кононенко, О.М.Пехоти, О.П.Рудницька та багато інших. Гуманізація освіти та формування гідного високорозвиненого члена 
суспільства стоїть на перехресті декількох дисциплін, а саме - філософії, психології, культурології та ін.

Провідною метою статті є окреслення стану української вищої гуманітарної освіти та виявлення тих чинників, які дадуть можливість в умовах глобалізованого суспільства виховати морально стабільну особистість, яка в своїх вчинках та діях послуговуватиметься високими нормами поведінки.

Цілком очевидно, що тільки за допомогою гуманізації освіти можна підвищити наш інтелектуальний рівень, навчити людину мислити, а отже, й діяти. Гуманітарна освіта покликана розширити розуміння людиною самої себе, на противагу природничим наукам, які надають лише чисте знання і мало сприяють рефлексії. Так, М.Романенко в своїх дослідженнях зазначає: «Якщо раніше основним компонентом навчально-виховного процесу були знання, то зараз особистісний розвиток і формування цілісної особистості. Важливо, щоб з ранніх етапів професійного становлення студенти почали осмислення свого ціннісного простору, побачили зв'язок із цілями й завданнями обраної професії, а також були залученими у спеціально організовану роботу з розвитку своїх смислових орієнтирів» $[4,174]$.

Гуманітарна освіта має формувати професійного фахівця, людину з цілковито сформованим світоглядом, зі своєю власною думкою, цінностями, ідеалами, переконаннями. Гуманістичні вектори сучасної освіти орієнтовані на всебічний розвиток студента, реалізацію його потенціалу, формування певних умов для повноцінної реалізації всіх його потенцій та задатків. Передумови, які формуються в гуманітарній освіті, мають слугувати певною рушійною силою для якісних змін в усьому суспільстві. Адже, керуючись ідеалами гуманізму, цінності кожного члена суспільства як особистості, людської свободи, ми можемо досягти права на власний незаангажований вибір чесності, справедливості, рівності всіх, тільки спираючись на якісну гуманітарну освіту, покликану формувати всі ці ідеї у молоді. Відтак ми отримаємо високорозвинуте, соціокультурне, наукове, сучасне суспільство, в якому існуватиме повага не лише до батьків, але й до власної нації, до ії інтелектуальних надбань, сформується високий рівень патріотизму та гідності за себе та свою державу. А дегуманізація української освіти може призвести до загрози знищення не тільки «особистості» в кожному з членів суспільства, але й власної української держави. 
Гуманітарна освіта формує та виховує високорозвинуту особистість та професіонала, а технічна освіта - суб'єкта природничого пізнання, відтак вона не зосереджує уваги на повноті людського буття, на проблемі формування особистості - іiі увагу привертають лише ті знання, що позбавленні суб'єктивного забарвлення. Показовими в даному контексті є зауваження Арістотеля, який у творі «Політика» доводить, що «законодавець повинен поставитися 3 винятковою увагою до виховання, оскільки в тих державах, де цього немає, і самий державний лад зазнає збитків. Адже виховання має відповідати кожному державному ладу...» $[1,628]$.

Основи гуманізації освіти в Україні закладено в нормативних документах 90-х pp. XX ст., які визначили напрям їі розвитку. «Гуманістичний підхід до освіти розглядається в цих документах як можливість подолання недоліків організаційно-виховного процесу вищої освіти - ії знеособлювання, зневага до суб’єктів навчального процесу, як кардинальна зміна спрямування діяльності освіти взагалі» $[3,63]$. Саме тому потрібно починати зі зміни головних постулатів, на яких будується вся українська освіта, а саме - мети, засобів та методів освітнього процесу, місця педагога та ін. Метою має постати різнорівневий комплексний розвиток особистості, але при цьому не треба знищувати набуття знань, умінь та навичок з конкретної спеціальності. Освіта має давати не тільки наукові настанови, але й культурологічні та світоглядні. Не останнє місце має посідати гармонійне поєднання наукового вивчення матеріалу 3 індивідуальним саморозвитком молоді. Як стверджував дослідник освітніх процесів І. Бех, «морально-духовна вихованість молодої особистості нині $€$ пріоритетною метою освітньої системи» $[2,11]$.

Освіта, як елемент гуманітарного розвитку держави, має забезпечувати висококваліфікованими фахівцями усі сфери життедіяльності. Саме вона повинна стати тим фундаментом, на якому розбудовуються нація та національність. «Оцінюючи стан і перспективи розвитку української освіти, зокрема вищої, першочергової уваги потребує розуміння ії націєтворчої ролі, яка повинна бути зреалізована шляхом виховання високоморальної, національно свідомої особистості. Це завдання освітньої галузі значно складніше і, мабуть, відповідальніше, ніж надання знань, умінь, навичок» [7]. Отже, гуманітарна освіта має забезпечувати студентів фундаментальними знаннями. Тільки тоді ми отримаємо те, до чого прагне кожне суспільство, яке 
хоче показати свою цінність на світовій арені.

Реформи, які впроваджуються сьогодні в нашому суспільстві, $\epsilon$ неоднозначними. 3 одного боку, ми прагнемо до європеїзації, завдяки якій гуманітарна освіта займає більшу частину навчального процесу, навіть серед технічних спеціальностей, а з іншого - маємо стан української гуманітарної освіти, який не є відповідно потужним.

Питання про новий тип людини та суспільства, який має грунтуватися на цілісному та інтегрованому розумінні духовного світу особистості, постає особливо актуальним наприкінці ХХ ст. Змінюється парадигма філософування, змінюється людство. Саме тому В.Пуляєв у своїй книжці «Час розкидати каміння минув, настав час їх збирати» пише: «Визнання в людині тільки «homo oikonomicus» власника, виробника, того, хто споживає матеріальні блага, - однобічна точка зору, обмежена і саме тому пригнічена. Економіка становить умови реальної соціокультурної динаміки. Зміст руху - в людині, iï культурі, освіті, науковому розвитку, творчості, здоров ї. Техніка, матеріали, продукти, прибуток, влада самі по собі (попри всі безперечні їх значення) виступають як моменти розвитку і утвердження людини. Вони являють собою лише засоби розширення, збагачення, розгортання багатоманітної культурної діяльності людини, іiі здібностей, духовного світу» $[6,7]$. Отже, не може йтися лише про владу машин, дія яких спрямована на задоволення людських потреб.

Формуванню постнекласичної парадигми освіти значною мірою сприяв процес глобалізації, який постає сучасним етапом розвитку єдиного і універсального проекту модерну, виявляючись у русі до універсального економічного, правового, інформаційного та освітнього простору. Глобалізація, реалізуючи спотворені капіталізмом ідеї епохи Модерну, зокрема, перебудови суспільства на просвітницьких засадах розуму, рівності й свободи, спрямована на розвиток ринкової економіки, представницької демократії, системи захисту прав і свобод людини та проявляється, з одного боку, у країнах Заходу, у їх своєрідній домодернізації, а з іншого - у малорозвинених країнах, що вимагають повної модернізації.

Процес глобалізації та інформаційна революція не лише інтегрують, але й невпинно інтенсифікують всі сфери життя людини. Перехід до постіндустріального інформаційного суспільства зумовив зміну в ритмі суспільного життя, яке перетворилося на постійне змагання людей, організацій і країн за володіння інформацією та 
знаннями. Країни-лідери змагаються за «інноваційний ресурс», який забезпечує випереджаючий розвиток.

Намагаючись дати відповідь на виклики інформаційного суспільства та глобалізації, постнекласична парадигма освіти формує ідеал автономної самодостатньої людини. Цікаво, що змістове наповнення парадигмі надає сучасна культура, адже ідея автономії панувала і в попередніх педагогічних парадигмах. Зокрема, в політичних творах давньогрецьких філософів цей термін означав незалежність від тиранії чи правління іноземців: автономні держави ті, що встановлюють власні закони. У середньовічній політичній теорії проблему автономії не обговорювали, але цей термін було запроваджено в політичних дискусіях через ранню новоєвропейську юриспруденцію. Поширення цього поняття на сферу особистісних відносин цілком і повністю належить І.Канту, звернення якого до феномену автономії спочатку було пов'язане із традиціями політичної теорії, однак згодом він скористався цим поняттям для аналізу індивідуального суб'єкта, а не держави. Аналізуючи дану проблему на рівні особистості, І.Кант підкреслює, що в буквальному значенні слово «автономія» («авто» - само, «номія» від грецького слова «номос» - закон) означає власне формування закону. При цьому «номос», за І.Кантом, - це не об'єктивна (природна) необхідність, а закон, створений волею людини, яка є ключем до вирішення всіх проблем моралі й відповідних їм обов’язків. Своєю чергою, будь-яка гетерономія довільного вибору, на думку мислителя, не створює обов'язковості й протистоїть іiі принципу моральності волі, яка виражає автономію практичного розуму, тобто волю й гідність людини.

Необхідність філософського обгрунтуванням волі людини пов'язана $з$ усвідомленням занепаду попередньої світоглядної традиції, яка вбудовувала людину в твердо встановлений надчасовий порядок - космічний (у досократиків) або ейдетичний (у Платона). Транслятором цієї влади в земному житті в античній культурі виступала держава, а в середньовічній теології - церква. Освіта, аналогічно до інших соціальних інститутів, розглядалася як службова сфера владних інстанцій. Згодом, в епоху Відродження, вчення про людину та іiі волю починає відокремлюватися від теології й стає відкритою альтернативою в умовах Нового часу. Це - новий етап розвитку автономії людини в суспільстві: тепер вона реалізується не тільки привілейованими станами, що управляють державою й 
церквою, але й ширшими прошарками населення.

Новий виток розвитку принципу автономії відбувається у XIX столітті.

Зокрема, він проявляється у творчості німецького педагога А.Дистервега, який обстоював ідеологічну, національну та станову автономність освіти, спрямовану на формування самостійної особистості. Проте світоглядні передумови цих ідей сформувалися ще у філософії Просвітництва, представники якої вважали, що незаангажованість системи освіти є головним засобом утвердження свободи волі людини й розумного врегулювання суспільства. Разом 3 тим, звільнюючи людину від «потойбічних» сил (М.Вебер), просвітницькі мислителі прагнуть підкорити людину новому типу «позачасового порядку» - не менш жорстким законам природи й історії. Така подвійність пронизує засадничі ідеї й цінності освіти наступної епохи індустріального суспільства - модерну.

Традиційна європейська освіта індустріального суспільства, відповідаючи на запит часу, сформувала власний ідеал людини, яким виступав добротний професіонал, цілком відповідний потребам суспільства масового добробуту. Як наслідок, освіта цього періоду була адаптативною і прагматичною. Тобто вона здійснювала соціалізацію особистості, була засобом іiі адаптації до існуючого економічного, соціального та культурного життя. Лише соціалізований індивід здатний брати участь у спільних, погоджених діях 3 іншими людьми на основі чітко визначених соціальних цінностей або норм. Загалом, адаптивна освіта епохи Модерну була спрямована на інтеграцію індивіда в соціум, тобто - суспільно орієнтованою, а людина та іiі розвиток поставали лише як другорядна мета. Призначення освіти - репродуктивне навчання та виховання, засвоєння системи знань, норм і цінностей, які дають змогу адаптуватися в суспільстві. 3 одного боку, вона формувала індивіда як особистість, а з іншого - перетворювала особистість у функціонера, здатного впроваджувати технологічні новації в усі сфери життя. Головним принципом життя людини-функціонера стає бажання мати й володіти. 3 одного боку - мати знання престижно, а 3 іншого- освіта дозволяє успішно рухатись вгору соціальною драбиною й забезпечити комфортне життя. У підсумку така соціалізована особистість виявляє, з одного боку, консерватизм дій і мислення, а 3 іншого - є зовсім байдужою до наслідків своєї діяльності й 
реагує лише на ті зміни, які зачіпають їі соціально-економічні інтереси, впливаючи на добробут. Однак комфортність життя не рівнозначна його екологічній та соціальній справедливості.

Суспільство масового добробуту вичерпало свій науково-технічний оптимізм і на практиці показало, з одного боку, свою несправедливість до людини та довкілля, а з іншого - неспроможність вирішити ті проблеми, які саме й породило. Завдяки усвідомленню проблем, породжених споживацькими цінностями індустріального суспільства, сьогодні формується новий ідеал успішного суспільства. Його репрезентує концепція сталого розвитку. В іiі змісті виокремлено два імперативи: екологічної та соціально-економічної сталості як практичного втілення суспільної справедливості.

Соціокультурні та цивілізаційні зміни сьогодення зумовлюють необхідність сформувати не лише нові суспільні цінності та норми, але й людину, яка усвідомлює відповідальність за збереження довкілля та соціальний добробут, здатна швидко навчатися й регулювати будь-які зміни. Загалом, сучасне суспільство вимагає ставлення високоосвіченої людини, яка конструює себе, творить власний проект самореалізації, крім того - творить довкілля: соціальноекономічне, матеріальне, культурно-духовне, екологічне. Автономна і самодостатня людина вільно й творчо реалізує свій потенціал, орієнтуючись на національні та загальнолюдські цінності. Опановуючи оцінки, моральні норми, взірці поведінки, самодостатня особистість виконує соціальні ролі не на основі примусу, а вільно, як акт власного свідомого вибору. Визначаючи міру свободи самореалізації особи, ідентичність дозволяє солідаризуватися з діями та вчинками інших людей на засадах справедливості, жити й діяти, зберігаючи власну гідність.

В ідеалі самодостатня особа $є$ творчо активною, здатною самостійно діяти й приймати рішення в постійно зміюваних умовах. Однак iї дії культурно осмислені. Для неї культура - не сума знань, а культура мислення: орієнтація на інновації, сприйняття нових ідей, готовність їх реалізувати, вміння критично ставитись до вже знаного, підійти до проблеми з усіх боків, з'ясувати різні погляди.

На формування нового ідеалу людини - автономної і водночас «заангажованої» в соціокультурне життя особистості - спрямована сучасна постнекласична парадигма освіти. Вона ідентифікує кожного як особистість і формує соціально значущі ракурси ідентичності, 
інтегруючи їх в особистісну ідентичність. В останній мають бути органічно поєднані такі їі іпостасі, як національна, громадянська, сімейна, професійна, екологічна тощо.

За допомогою навчання людина здобуває досвід попередніх століть, з одного боку, навчаючись чинити, як ії предки, та розуміти світ відповідно до традицій роду, а з іншого - вчиться жити в суспільстві, посідати своє законне місце в ньому, намагається прилаштовуватися до нових умов, які є досить швидкозмінними. Саме для того, аби сприймати світ повніше, не заангажовано, уникати конфліктних наслідків, чинити правильно, відповідно до загальних вимог, потрібна філософія освіти, яка може бути гнучкою до всіх змін у суспільстві та має всі можливості для створення схем освітнього процесу, який змінюється під натиском суспільних перетворень.

Філософія освіти покликана навчити людину сприймати світ, як повноцінну картину, та себе в ньому - як цілісну особистість. Адже кожне суспільство має забезпечувати свою повноцінну життєдіяльність, а для цього потрібні високорозвинуті особистості, які діють відповідно до конкретних норм поведінки, встановлених у ньому. Саме за таких умов працюють соціальні інститути. Людина постає об’єктом гуманітарної освіти, адже саме для неї, задля іiі блага і потрібна гуманітарна освіта, а розуміння суспільства підпадає під рівень соціальних наук. Поєднання та гармонізація міждисциплінарних принципів дає нам надію на успіх у формуванні нових стереотипів держави, які задовольняють суспільство і кожного iii члена. Отже, проблема людини стає центральною в осмисленні сучасних соціокультурних процесів. Дослідження iї потребує поєднання наукового, культурологічного та світоглядного знання.

Починаючи 3 ідей Платона про освіту та процес отримання знання і далі - з виникнення гуманізму в епоху Відродження, крізь антропологічний поворот і до сьогодення в будь-якій моделі освіти найважливіше місце займає гуманітарна освіта. Саме вона, як зазначає Л.Мосолова, є духовною основою буття людини та суспільства. Значення цього полягає передусім у тому, що вона зберігає та стверджує змістотворчі координати всієї культурної системи, формуючи духовно цілісну особистість. Метою гуманітарної освіти є формування образу особистості, яка максимально повно та гармонійно виражає всі сутнісні сили людини» $[5,27]$. М.Шеллер запропонував розуміти освіту не лише як процес здобуття знання, а й як

ISSN2078-8142 Мультиверсум. Філософський альманах.-2015.-Випуск 1-2(139-140) 165 
формування, становлення духу, як цілісний процес створення людини. Описуючи класичний порядок розвитку особистості, він у своїх працях показував, як типи знань, котрі традиційно склалися в культурі, залежать він фундаментальних здібностей людського духу. Але в сучасному суспільстві сильніше виявляється зворотна залежність типу знань особистості від домінуючих форм знання та освіти.

Нині людина не тільки має опанувати певну сукупність знань, але й вміти знаходити нову інформацію, не залежно від можливостей. Щоб вирішити ту чи іншу проблему, слід уміти володіти та користуватися різними витоками інформації - вирішення сучасних проблем постійно потребує все нові та нові знання. Відбувається зміна пріоритетів зі звичайного накопичення знання на вміння пізнавати: сучасному соціуму потрібні люди, які вміють навчатися, а не просто зазубрювати матеріал, потрібні мислячі особистості, які самостійно можуть заволодівати інформацією. Саме тому гуманізація освіти звертається безпосередньо до можливостей особистості, iї творчої індивідуальності. Гуманітарні принципи стають домінантними системотворчими компонентами нової системи освіти, яка, своєю чергою, займає дуже важливе місце в соціальному розвитку суспільства, формує суспільство інформаційне, високотехнічне та гармонійне.

Отже, як висновок потрібно сказати, що формування цілісної гуманітарної освіти відбувається за тих обставинах, коли філософські, культурологічні, соціальні, суспільні та природничі науки формують свої основи на вивченні та дослідженні розуміння людини, іiі суб'єктивної індивідуальності та цілісності людської істоти і їі буття. На сучасному етапі розвитку філософського знання вирізняють два основні проблемні кола, на яких грунтується гуманітарна освіта, а саме: 1) офіційна система, та, яку нам пропонує влада, суттєво відрізняється від інтересів та цінностей сучасних людей, 2) освіта не здійснює функцію виховання того типу світогляду, за допомогою якого ми б могли вирішити глобальні проблеми людства. Щоб вирішувати їх, потрібно розробити власну філософську методологію сучасної освіти, яка має включати в себе міждисциплінарні дослідження, котрі враховують, своєю чергою, стан сучасної особистості та розвиток природничих наук. 


\section{ЛIТЕРАТУРА}

1. Аристотель. Сочинение: в 4-х.т. Т.4. - М., 1984. - С. 628.

2. Бех Іван. Законопростір сучасного виховного процесу // Вища освіта України. - 2004. - № 1. - С. 10-13.

3. Запесоикий А.С. Образование: философия, культурология, политика. M., 2002. $-456 \mathrm{c}$.

4. Романенко M.I. Гуманізація освіти: концептуальні проблеми та практичний досвід. - Дніпропетровськ, 2001. - 256 с.

5. Мосолова Л.М. Междисциплинарность гуманитарного образования: философско-онтологические основания // Universum: Вестник Герценовского университета. - 2008. - №8.

6. Пуляев В.T. Время разбрасывать камни прошло, наступило время их собирать // Гуманитарий. - СПб., 1995. - №1.

7. Україна в контексті проблем якісної освіти [Електронний ресурс]. Режим доступу: http: // www.anvsu.org.ua/index.files/Articles/Drobnokhod3.htm

8. Філософія освіти / Чекаль Л.А., Гейко С.М., Горбатюк Т.В. та інші. Київ ; Ніжин, 2014. - 264 с.

Сторожук С.В., Матвієнко І.С. Вища гуманітарна освіта та можливості формування моральної особистості в умовах сучасного суспільства.

Стан гуманітарної освіти в Україні зумовлює тривалі дискусії, які точаться навколо нагальних проблем, посталих в українському суспільстві. Гуманітарна освіта покликана розширити розуміння людиною самої себе, на противагу природничим наукам, які надають лише «чисте» знання і не сприяють рефлексії. Гуманістичні вектори сучасної освіти орієнтовані на всебічний розвиток студента, реалізацію його потенціалу, формування певних умов для повноцінної реалізації всіх його потенцій та задатків. Освіта, як елемент гуманітарного розвитку держави, має забезпечувати висококваліфікованими фахівцями усі сфери життєдіяльності. Саме вона має стати тим фундаментом, на якому розбудовуються нація та національність.

Ключові слова: освіта, гуманізація освіти, людина, особистість, суспільство.

Сторожук С.В, Матвиенко И.С. Высшее гуманитарное образование и возможности формирования нравственной личности в условиях современного общества.

Состояние гуманитарного образования в Украине приводит к острым дискуссиям, сосредоточенным вокруг острых проблем, возникшим в украинском обществе. Гуманитарное образование призвано расширить понимание человеком самого себя, в противовес естественным наукам, которые 
дают «чистое» знание и не способствуют мышлению. Гуманитарные векторы современного образования ориентированы на всестороннее развитие студента. Образование, как элемент гуманитарного развития страны, должно гарантировать высококвалифицированного специалиста во всех сферах жизнедеятельности. Именно оно должно стать тем фундаментом, на котором строятся нация и национальность.

Ключевые слова: образование, гуманизация образования, человек, личность, общество.

Storozhuk S.V., Matvienko I.S. Higher education in the humanities and the possibility of formation of a moral person in the conditions of modern society.

Condition of humanities education in Ukraine currently has continued discussions going on around the problems that arose in quite our Ukrainian society. Humanitarian education designed to expand understanding of himself, as opposed to science, providing only pure knowledge, and not mixed people think. Humanistic vectors of modern education aimed at comprehensive development of the student, the realization of its potential, the formation of certain conditions for the full realization of all potentials and inclinations of the student. Education as part of humanitarian security, should provide highly qualified specialists in all spheres of life. That it should be the foundation on which is built the nation and nationality.

Key words: education, humanization of education, people, person and society. 